FEDERAL RESERVE

BANK of

ST. LOUIS
RESEARCH DIVISION Working Paper Series

\title{
Foreign Aid, Illegal Immigration, and Host Country Welfare
}

\author{
Subhayu Bandyopadhyay, \\ Dustin Chambers \\ and \\ Jonathan Munemo
}

\author{
Working Paper 2012-007A \\ https://doi.org/10.20955/wp.2012.007
}

March 2012

\author{
FEDERAL RESERVE BANK OF ST. LOUIS \\ Research Division \\ P.O. Box 442 \\ St. Louis, MO 63166
}

The views expressed are those of the individual authors and do not necessarily reflect official positions of the Federal Reserve Bank of St. Louis, the Federal Reserve System, or the Board of Governors.

Federal Reserve Bank of St. Louis Working Papers are preliminary materials circulated to stimulate discussion and critical comment. References in publications to Federal Reserve Bank of St. Louis Working Papers (other than an acknowledgment that the writer has had access to unpublished material) should be cleared with the author or authors. 


\title{
Foreign Aid, Illegal Immigration, and Host Country Welfare
}

\author{
Subhayu Bandyopadhyay ${ }^{\mathrm{a}}$, Dustin Chambers ${ }^{\mathrm{b}}$, and Jonathan Munemo ${ }^{\mathrm{c}}$
}

March 2012

\begin{abstract}
$\underline{\text { Abstract }}$
This paper analyzes the effect of foreign aid on illegal immigration and host country welfare using a general equilibrium model. We show that foreign aid may worsen the recipient nation's terms of trade. Furthermore, it may also raise illegal immigration, if the terms of trade effect on immigration flows dominates the other effects identified in our analysis. Empirical analysis of the effect of foreign aid on illegal immigration to the United States broadly supports the predictions of our theoretical model. Foreign aid worsens the recipient's terms of trade. While the terms of trade effect tends to reduce illegal immigration, countervailing effects are found to dominate. The paper contributes to the related literature by establishing that there are unintended consequences of foreign aid, and, while some of them are reminiscent of the classical transfer problem, others are new and arise due to endogenous illegal immigration flows.
\end{abstract}

Keywords: Foreign aid, illegal immigration, terms of trade, transfer problem, tied aid JEL codes: $\mathrm{F} 1 ; \mathrm{F} 35 ; \mathrm{O} 1$

${ }^{\mathrm{a} C}$ Corresponding author. Research Division, Federal Reserve Bank of St. Louis, PO Box 442, St. Louis, MO 63166-0442. E-mail: bandyopadhyay@stls.frb.org; Tel: 314-444-7425; Fax: 314444-8731.

${ }^{\mathrm{b}}$ Department of Economics and Finance, Salisbury University, 1101 Camden Ave., Salisbury, MD 21801. E-mail: DLChambers@ @alisbury.edu; Tel: 410-543-6320; Fax: 410-546-6208.

${ }^{c}$ Department of Economics and Finance, Salisbury University, 1101 Camden Ave., Salisbury, MD 21801. E-mail: jxmunemo@ @alisbury.edu; Tel: 410-677-0057; Fax: 410-546-6208.

Any opinions, findings, and conclusions or recommendations are solely those of the authors and do not necessarily reflect the view of the Federal Reserve Bank of St. Louis, and the Federal Reserve System. 


\title{
Foreign Aid, Illegal Immigration, and Host Country Welfare
}

\begin{abstract}
$\underline{\text { Abstract }}$
This paper analyzes the effect of foreign aid on illegal immigration and host country welfare using a general equilibrium model. We show that foreign aid may worsen the recipient nation's terms of trade. Furthermore, it may also raise illegal immigration, if the terms of trade effect on immigration flows dominates the other effects identified in our analysis. Empirical analysis of the effect of foreign aid on illegal immigration to the United States broadly supports the predictions of our theoretical model. Foreign aid worsens the recipient's terms of trade. While the terms of trade effect tends to reduce illegal immigration, countervailing effects are found to dominate. The paper contributes to the related literature by establishing that there are unintended consequences of foreign aid, and, while some of them are reminiscent of the classical transfer problem, others are new and arise due to endogenous illegal immigration flows.
\end{abstract}

\section{Introduction}

The United States is increasingly relying on both border and internal enforcement measures to curb the rise of illegal immigrants from Mexico, and Central and South America. ${ }^{1}$ Figure 1 chronicles these intensified efforts along the U.S.-Mexico border. As a matter of fact, since the passage of the Immigration Reform and Control Act (IRCA) in 1986, the number of Border Patrol agents has tripled, the use of high-tech equipment such as unmanned spy planes with infra-red cameras has become routine, and a 15 foot high fence spanning 700 miles of the Mexican border is currently under construction. In addition to intensified border enforcement, internal enforcement efforts punish firms that employ illegal workers.

However, tougher enforcement at the border and workplace have, up to this point, failed to control illegal immigration. Numerous studies in the migration literature reach the same conclusion: the most effective way of bringing illegal immigration under control is to promote development in the emigration countries (see for example, Todaro and Maruszko, 1987, and, Faini and Venturini, 1993). In addition, other studies have demonstrated that foreign aid can

\footnotetext{
${ }^{1}$ According to Camarota (2007), half of Mexican and Central American immigrants, and one-third of South American immigrants in the United States are illegal. Media outlets such as The Economist (2004) have reported a significant increase in illegal immigrants from Central American countries such as Honduras, Guatemala, Nicaragua, and El Salvador entering the United States.
} 
reduce the incentive to emigrate by raising living standards in sending countries (see for example, Gaytan-Fregoso and Lahiri, 2000, Myers and Papageorgiou, 2000, and Djajic, 2007). However, none of the foregoing studies take into account that aid (and the resulting transfer of purchasing power) also affects the commodity terms of trade of recipient nations, and this in turn effects illegal immigration. In fact, to our knowledge, the commodity terms of trade effect of foreign aid on illegal immigration has not been addressed by the literature. In most studies, the commodity terms of trade are assumed to be exogenous, which implies that they have no effect on immigration (see for example Bond and Chen, 1987, Gaytan-Fregoso and Lahiri, 2000, and, Bandyopadhyay, 2006).

This paper considers the effect of foreign aid on illegal immigration and host country welfare when the commodity terms of trade are endogenous. We build a general equilibrium model with two countries (a donor/host country and a recipient) and two goods (a primary good and a manufactured good). The recipient country exports the primary good and imports the manufactured good (which is subject to a tariff). We show that foreign aid reduces the recipient's commodity terms of trade. The welfare of the host country is affected by three factors. The first is the commodity terms of trade gain due to the transfer. The second is the income loss resulting from the transfer. We know from Ohyama (1974) and Brecher and Bhagwati (1982) that in the presence of a tariff in the recipient country, the commodity terms of trade gain can dominate the income loss leading to a net welfare gain for the host country. Finally, the change in the terms of trade, and the direct effect of foreign aid on the recipient nation's productivity can both affect migration flows by changing the wage differential between the host and source nations of illegal immigration. To the extent that the immigration flows may reduce the wage earned by illegal immigrants, the host nation enjoys a terms of trade gain in the factor market from enhanced 
migration flows. This effect complements the standard terms of trade effects discussed in the literature in the context of the classical transfer problem.

To test the findings of our theoretical model, we empirically estimate the effect of foreign aid on illegal immigration flows to the United States. Our results are consistent with the predictions of the theoretical model. We find that the commodity terms of trade effect of foreign aid significantly increases illegal immigration to the United States. The results also support existing studies in the migration literature which find that foreign aid can reduce the incentive to emigrate by raising incomes in sending countries. In addition, we also find that illegal immigration is significantly increased by high unemployment in the sending country.

The rest of this paper is organized as follows: the theoretical model is presented in section 2, while section 3 discusses the empirical model, data, and estimation results, and finally section 4 concludes.

\section{The Model}

There are two countries, $A$ (a poor developing country) and $B$ (a rich developed country), and two goods, 1 (a primary good) and 2 (a manufactured good). As is standard in neoclassical trade models, we assume that nations have given factor endowments. To simplify the analysis, we assume that $B$ is specialized in the production of good 2, but consumes both goods. Country $B$ exports good 2 to nation $A$, and imports good 1 from it. Trade is assumed to be balanced. We assume that labor is of two types, skilled and unskilled. Wage rates of skilled and unskilled labor in nation $B$ are $w^{s B}$ and $w^{u B}$, respectively. The corresponding wage rates for nation $A$ are $w^{s A}$ and $w^{u A}$. Nation $B$ 's unskilled wage $w^{u B}$ is assumed to exceed $w^{u A} .^{2}$ We also assume that

\footnotetext{
${ }^{2}$ This may be due to $B$ 's superior technology, or because of endowment differences between the two nations, among other potential reasons.
} 
there is no legal immigration in the model, however, the wage difference for unskilled labor leads to illegal immigration of unskilled labor from $A$ to $B .{ }^{3}$ Country $B$ relies on border enforcement and internal enforcement to reduce the inflow of illegal immigrants. Let $I$ be the level of illegal immigration, and $W_{I}$ the illegal wage rate in $B$. Nation $B$ also makes a transfer of foreign aid to country $A$ of an amount $T$. Let $v^{A}$ and $v^{B}$ be the factor endowment vectors of $A$ and $B$, respectively. Treating good 1 as the numeraire, denoting the international price of good 2 by $p$, and the utility of a representative consumer in $A$ by $u^{A}$, the expenditure function of $A$ is $E^{A}\left(1, p+t, u^{A}\right)$, where $t$ is $A^{\prime}$ 's unit import tariff. We assume that $B$ follows free trade. Hence, using notation similar to $A$, we can express $B$ 's expenditure function as $E^{B}\left(1, p, u^{B}\right)$.

Under competitive profit maximizing conditions, and assuming that foreign aid may impact $A$ 's productivity, national income can be represented by its revenue function $R^{A}\left(1, p+t, v^{A}-I, T\right)$, where the argument $\left(v^{A}-I\right)$ represents the endowment vector net of unskilled emigration from $A .^{4}$ Similarly, Country $B$ 's national income is represented by its revenue function $R^{B}\left(1, p, v^{B}+I\right) .^{5}$ The partial of nation $j$ 's $(j=A, B)$ revenue function with respect to the price of good- $i(i=1,2)$ yields the general equilibrium supply function for good- $i$ by nation $j .{ }^{6}$ Similarly, the corresponding partials of the expenditure functions yield the Hicksian demand functions. In addition, the partials of the revenue functions with respect to the respective endowment vectors yield the respective factor reward vectors. We use the convention

\footnotetext{
${ }^{3}$ Following Ethier (1986), among others, we assume that there is no illegal immigration in the skilled category. This is also largely consistent in terms of stylized facts of the US-Mexico illegal immigration problem, where the vast majority of such workers are in the low wage unskilled sector.

${ }^{4}$ We are grateful to an anonymous referee for suggesting an analysis of this potential impact of aid on the revenue function. Of course, it is easy to see that the results are qualitatively unaltered if this effect is absent.

${ }^{5}$ For simplicity, we assume that $T$ does not enter $B$ 's revenue function.

${ }^{6}$ See Dixit and Norman (1980) for analysis of trade models using such dual functions.
} 
that for any function $f\left(x_{1}, x_{2}, \ldots x_{n}\right), f_{i}$ is the partial derivative of the function with respect to argument $i$, and $f_{i j}$ is the partial derivative of the function $f_{i}$ with respect to argument $j$.

Following Ethier (1986) and Bond and Chen (1987) we assume that nation B's government uses both internal enforcement $\left(e_{i}\right)$ and border enforcement $\left(e_{b}\right)$ to control illegal immigration. Internal enforcement leads to a fine of $z$ per illegal immigrant detected to be working for a representative firm. The firm pays this fine, but it also equates its marginal cost of hiring an unskilled native to that of the expected cost of hiring an illegal immigrant. Therefore, denoting the wage paid to an illegal immigrant as $w_{I}$, and the probability of internal detection by $\rho\left(e_{i}\right)$, we get:

$$
w_{I}+z \rho\left(e_{i}\right)=w^{u B} \Rightarrow w_{I}=w^{u B}-z \rho\left(e_{i}\right)
$$

Let the probability of being caught at the border be $g\left(e_{b}\right)$, and let there be a loss of wages to the tune of $k$ for a potential immigrant who is caught at the border, and returned to nation $A .^{7}$ Assuming risk neutrality, the equilibrium migration condition equates the certainty wage for unskilled workers in nation $A$ to the expected wage in nation $B$. Therefore, along the lines of Ethier (1986), we get:

$$
w^{u A}=g\left(w^{u A}-k\right)+(1-g) w_{I} \Rightarrow w^{u A}=w_{I}-\beta\left(e_{b}\right), \beta\left(e_{b}\right) \equiv \frac{k g\left(e_{b}\right)}{1-g\left(e_{b}\right)}
$$

Using (2.1) and (2.2):

$$
w^{u A}=w^{u B}-z \rho\left(e_{i}\right)-\beta\left(e_{b}\right)
$$

Balanced trade requires that $A$ 's expenditure equals the sum of its production revenues, foreign aid receipts, income earned by illegal immigrants, and tariff revenue.

\footnotetext{
${ }^{7}$ For example, this may take the form of potentially productive time being lost in the process of waiting to be deported.
} 


$$
E^{A}\left(1, p+t, u^{A}\right)=R^{A}\left(1, p+t, v^{A}-I, T\right)+T+\left[w^{u B}-z \rho\left(e_{i}\right)-\beta\left(e_{b}\right)\right] I+t\left(E_{2}^{A}-R_{2}^{A}\right)
$$

Equation (2.4) implicitly defines $u^{A}$ as:

$$
u^{A}=u^{A}\left(t, p, I, T, e_{i}, e_{b}\right)
$$

There are two things to notice before we present the expenditure-revenue relationship for $B$.

First, the cost to $B$ of hiring an illegal immigrant is $w_{I}=w^{u B}-z \rho$, because the fines collected from the employers are paid back to the natives of $B$ by its government. As noted in Bond and Chen (1987), $z \rho$ is essentially a tax that is borne by the illegal immigrant, whose benefit accrues to nation $B$. Second, the expected cost $\beta\left(e_{b}\right)$ is also borne by the illegal immigrant, and is a loss to nation $A$ [see Eq.(2.4) above], but unlike $z \rho$ it has no direct impact on $B$ 's national income. Nation $B$ 's expenditure-revenue identity is given by

$$
E^{B}\left(1, p, u^{B}\right)=R^{B}\left(1, p, v^{B}+I\right)-T-\left[w^{u B}-z \rho\left(e_{i}\right)\right] I-e_{i}-e_{b}
$$

Equation (2.6) implicitly defines $u^{B}$ as

$$
u^{B}=u^{B}\left(p, I, T, e_{i}, e_{b}\right)
$$

Using the fact that the partial of the revenue function with respect to the endowment vector must yield the factor reward vector, we can rewrite Eq. (2.3) as:

$$
R_{v}^{A}\left(1, p+t, v^{A}-I, T\right)=R_{v}^{B}\left(1, p, v^{B}+I\right)-z \rho\left(e_{i}\right)-\beta\left(e_{b}\right)
$$


Eq. (2.8) implicitly defines ${ }^{8}$

$$
I=I(t, p, T)
$$

It is easy to check that $R_{v v}^{B}<0$ in our model, where nation $B$ produces a single good through a constant returns to scale production function. Also, $R_{v 2}^{B}=\frac{\partial w^{u B}}{\partial p}>0$, because in this single good set-up for $B$, the rise in the price of the good must raise both factor rewards. Concavity in factor endowments guarantees that $R_{v v}^{A} \leq 0 .{ }^{9}$ However, the sign of $R_{v 2}^{A}=\frac{\partial w^{u A}}{\partial(p+t)}$ needs some careful analysis. Good 2 is the manufactured good and is therefore likely to be skill intensive. If $A$ 's production structure follows the Heckscher-Ohlin model, then the Stolper-Samuelson theorem will predict that a rise in the price of good 2 will reduce the unskilled wage. In other words, it will predict that $R_{v 2}^{A}=\frac{\partial w^{u A}}{\partial(p+t)}<0$. To reduce the taxonomy of possible cases, we will assume that $R_{v 2}^{A}<0$, in the rest of the analysis. The other cases can easily be worked out, as necessary. Given these assumptions, Eqs. (2.8) and (2.9) can be used to get

$$
I_{t}=\frac{R_{v 2}^{A}}{R_{v v}^{A}+R_{v v}^{B}}>0 ; I_{p}=\frac{R_{v 2}^{A}-R_{v 2}^{B}}{R_{v v}^{A}+R_{v v}^{B}}>0 ; \text { and } I_{T}=\frac{R_{v T}^{A}}{R_{v v}^{A}+R_{v v}^{B}} \leq 0,
$$

where $R_{v T}^{A} \geq 0$, because aid is assumed to either be neutral or helpful in terms of $A$ 's production capabilities.

\footnotetext{
${ }^{8}$ From this point, we suppress the enforcement vector $\left(e_{i}, e_{b}\right)$ from the functional forms for ease of exposition. This is innocuous because the analysis assumes the enforcement levels to be given.

${ }^{9}$ For example, strict concavity of the revenue function is satisfied by the specific factors model, but not the standard Heckscher-Ohlin model, where factor returns are independent of factor endowments implying that $R_{v v}^{j}=0$.
} 
Using Eqs. (2.5), (2.7) and (2.9) in the expenditure and revenue functions of the two nations, we get the market clearing equation for good 2 as

$$
\begin{aligned}
& E_{2}^{A}\left[1, p+t, u^{A}\{t, p, I(t, p, T), T\}\right]+E_{2}^{B}\left[1, p, u^{B}\{p, I(t, p, T), T\}\right] \\
& =R_{2}^{A}\left[1, p+t, v^{A}-I(t, p, T), T\right]+R_{2}^{B}\left[1, p, v^{B}+I(t, p, T)\right] .
\end{aligned}
$$

Suppressing the factor endowment vectors $v^{A}$ and $v^{B}$, Eq. (2.11) implicitly defines the international price of good 2 (also the terms of trade of nation $B$ ) as

$$
p=p(t, T)
$$

Given an import tariff $t$ and a foreign aid level $T$, and for given enforcement levels, Eq. (2.12) determines the international price of good 2. In turn, Eq. (2.9) determines the illegal immigration level. Using this price level and the illegal immigration level we can solve for the utility levels in the two nations from equations (2.5) and (2.7). The system defined above can then be used to solve for all the other variables of interest.

\subsection{The effect of foreign aid on terms of trade and illegal immigration}

A simple way to understand the effect of foreign aid on the terms of trade is to focus on the case when aid has no effect on $A$ 's revenue function. ${ }^{10}$

$$
p_{T}=\frac{\partial p}{\partial T}=\frac{\left(\frac{E_{2 u}^{A}}{E_{u}^{A}-t E_{2 u}^{A}}-\frac{E_{2 u}^{B}}{E_{u}^{B}}\right)}{D},
$$

\footnotetext{
${ }^{10}$ The analysis of the terms of trade involving $T$ in the revenue function is somewhat more complex, and is less clear in terms of exposition. The results are available from the authors on request.
} 
where $D$ is the slope of the global excess supply function of good-2, and must be positive for stability of international equilibrium (i.e., the Marshall-Lerner condition requires that $D>0$ ). The expression in the numerator of the last term of Eq. (2.13a) is the familiar marginal propensity condition of the transfer problem. If the marginal propensity to consume good- 2 of nation $A$ (i.e., the recipient nation) exceeds that of the donor nation $B$, it raises its demand for good 2 by a larger amount than $B$ 's reduction in demand for good 2 . In this situation, on balance, the global demand for good-2 must increase. This will lead to a rise in the international price of good-2. A simple case where terms of trade for $B$ must improve is when $B$ is specialized in the consumption of good 1. In that case, the numerator of Eq. (2.13a) must be positive, because it will be independent of any terms involving nation $B$. For ease of exposition, for the rest of the analysis, we assume that $A$ 's demand augmenting effect dominates. Thus,

$$
p_{T}>0
$$

\section{Case 1: Untied foreign aid}

Differentiating (2.9), and using Eqs. (2.10), (2.12) and (2.13b), we get:

$$
\frac{d I}{d T}=I_{p} p_{T}+I_{T} \Rightarrow \frac{d I}{d T}>0 \text { iff } p_{T}>\frac{\left|I_{T}\right|}{I_{p}}
$$

This equation suggests that there are two opposing effects that determine the sign of $\frac{d I}{d T}$. From Eq. (2.10) it is clear that if the effect of $T$ on $A$ 's revenue function is small, the term $\left|I_{T}\right|$ is likely to be small. In this case, Eq. (2.14) suggests that $\frac{d I}{d T}>0$. On the other hand, if the productivity enhancing effect dominates, then aid reduces illegal immigration. The intuition is the following. 
When the terms of trade effect is strong, the rise in $B$ 's unskilled wage and the fall in $A^{\prime}$ 's unskilled wage (due to a rise in $p$ ) will tend to encourage migration. On the other hand, if aid raises productivity in $A$, it will raise $A$ 's unskilled wage, and this will tend to reduce migration. The net effect depends on the relative strength of these opposing factors. This adds a new twist to the traditional transfer problem by raising the possibility that foreign aid and the associated changes in the terms of trade can undermine a nation's efforts to control illegal immigration.

\section{Case 2: Foreign aid is tied to trade liberalization}

Suppose foreign aid is given on the condition that country $A$ liberalizes trade by reducing its tariff on good 2, such that $t=t(T)$, and $t^{\prime}=\frac{d t}{d T}<0$. Differentiating (2.9), and using Eqs. (2.10), (2.12) and (2.13b), we get:

$$
\frac{d I}{d T}=\left(I_{p} p_{t}+I_{t}\right) t^{\prime}+I_{p} p_{T}+I_{T}
$$

Using Eqs. (2.11) and (2.12) it can be shown that $p_{t}$ is negative under reasonable assumptions on tariff induced immigration flows. This is intuitive, because normally one would expect an import tariff to reduce the world price of the import good. If $I_{p} p_{t}+I_{t}<0$, then Eq. (2.14) and

Eq. (2.15) jointly imply that $\frac{d I}{d T}>0$. The term $\left(I_{p} p_{t}+I_{t}\right) t^{\prime}$ captures the induced effect of trade liberalization, while the remaining terms reflect the terms of trade effects discussed in case 1.

\subsection{The effect of foreign aid on the welfare of the host country}

For the welfare analysis we consider case 1 above of untied aid, and also suppress the enforcement variables from the functional forms. Using Eqs. (2.7), (2.9) and (2.12) 


$$
u^{B}=u^{B}(p(t, T), I\{t, p(t, T)\}, T) .
$$

Differentiating (2.16)

$$
\frac{d u^{B}}{d T}=\left(u_{p}^{B}+u_{I}^{B} I_{p}\right) p_{T}+u_{I}^{B} I_{T}+u_{T}^{B}
$$

Using Eqs. (2.6) and (2.7), we can show that

$$
u_{p}^{B}=\frac{\operatorname{Exp}_{2}^{B}-I R_{v 2}^{B}}{E_{u}^{B}}, u_{I}^{B}=\frac{z \rho-I R_{v v}^{B}}{E_{u}^{B}}>0, u_{T}^{B}=-\frac{1}{E_{u}^{B}}<0, \operatorname{Exp}_{2}^{B}=R_{2}^{B}-E_{2}^{B},
$$

where $E_{u}^{B}$ is the inverse of the marginal utility of income and is positive, and $\operatorname{Exp}_{2}^{B}$ is the export of good 2 by $B$, and is also positive. As long as $I R_{v 2}^{B}$ is not too large in absolute value, Eq. (2.18) suggests that $u_{p}^{B}$ is positive. This is intuitive, because one would expect that the direct effect of a rise in the price of $B$ 's export good will raise its utility. The term $u_{I}^{B}$ is positive because $B$ 's wage falls due to more immigration (i.e., $R_{v v}^{B}<0$ ), and this confers a terms of trade gain to $B$ in the unskilled labor market, and also because an immigrant works at a lower wage than her/his marginal product (this gain is reflected in the term $z \rho$ ). The term $u_{T}^{B}$ measures the direct effect of making a transfer to nation $A$, which must then reduce $B$ 's utility. Using Eqs. (2.14) and (2.18) in Eq. (2.17) we can infer that while the direct effect of the transfer is to reduce $B$ 's utility, the indirect effects arising out of terms of trade improvement for $B$ tend to improve its welfare because of the traditional transfer problem type effects, and also because of the induced immigration flows. Ohyama (1974) and Brecher and Bhagwati (1982) demonstrate that in the presence of a tariff in the recipient country, the terms of trade gain can dominate the income loss 
leading to a net welfare gain for the host country. We complement these results by showing that immigration flows may augment such a welfare enhancing effect for the donor nation.

\subsection{A simple model of unemployment ${ }^{11}$}

This subsection presents a model along the lines of Ethier (1986) and Palivos (2009) where there is a minimum wage for unskilled labor in nation $B$. For simplicity, for this subsection we assume that $T$ has no effect on $A$ 's revenue function, and also that border enforcement is the only form of enforcement (i.e., $e_{i}=0$ ). These assumptions are not restrictive and do not affect the qualitative nature of the results. Let the constant returns to scale production function of good 2 in $B$ be

$$
X_{2}=f(L, S), f_{j}>0, f_{j j}<0, j=L, S
$$

where $L$ and $S$ are the unskilled and skilled labor employed in producing the good. Let the minimum wage for unskilled labor be $w^{u B}=\bar{w}$. The profit of a representative firm is

$$
\pi=p f(L, S)-\bar{w} L-w^{s B} S
$$

The first order conditions require that

$$
p f_{L}(L, S)=\bar{w}, \text { and, } p f_{S}(L, S)=w^{s B}
$$

Let the skilled labor endowment of nation $B$ be $\bar{S}$. Substituting $S=\bar{S}$ in Eq. (2.21a), we get

$$
L=L(p, \bar{w}, \bar{S}), L_{p}=-\frac{\bar{w}}{p^{2} f_{L L}}>0 ; \text { and } w^{s B}=p f_{S}[L(p, \bar{w}, \bar{S}), \bar{S}]=w^{s B}(p)
$$

Let the given stock of $B$ 's unskilled natives be $\bar{L}$. The total unskilled labor supply is $\bar{L}+I$. If the minimum wage is binding, there is unemployment, implying that $L<\bar{L}+I$. Let the

\footnotetext{
${ }^{11}$ Following the suggestions of an anonymous referee we consider an extension of the framework we describe above by allowing for a minimum wage and unemployment in the unskilled labor market of nation B.
} 
employment rate be denoted by $m$. Then, using Eq. (2.21b) and suppressing $\bar{w}, \bar{L}$ and $\bar{S}$ from the functional forms, we get

$$
m=\frac{L(p)}{\bar{L}+I} \equiv m(p, I)<1
$$

Notice that in the presence of unemployment, and assuming that there is no internal enforcement, the expected wage that a potential migrant faces if she/he successfully crosses the border is $m \bar{w}$. The migration condition [along the lines of Eq. (2.2) above] is:

$$
w^{u A}=g\left(w^{u A}-k\right)+(1-g) m \bar{w} \Rightarrow w^{u A}=m \bar{w}-\beta\left(e_{b}\right), \beta\left(e_{b}\right) \equiv \frac{k g\left(e_{b}\right)}{1-g\left(e_{b}\right)} .
$$

Eq. (2.23a) reduces to

$$
R_{v}^{A}\left(1, p+t, v^{A}-I\right)=\bar{w} m(p, I)-\beta\left(e_{b}\right)
$$

Suppressing $t$ and $e_{b}$ from the functional forms, Eq. (2.23b) implies that

$$
I=I(p, m), \text { where } I_{p}=\frac{R_{v 2}^{A}}{R_{v v}^{A}}>0, \text { and } I_{m}=-\frac{\bar{w}}{R_{v v}^{A}}>0
$$

Substituting $(2.23 \mathrm{c})$ in $(2.22)$ we get

$$
\begin{aligned}
& m=\frac{L(p)}{\bar{L}+I(p, m)} \Rightarrow m=m(p) \\
& \text { where } m^{\prime}(p)=\frac{d m}{d p}=\frac{L_{p}-m I_{p}}{\bar{L}+I+m I_{m}}>0 \text { iff } L_{p}>m I_{p}
\end{aligned}
$$

The balanced trade condition for this economy is:

$$
E^{B}\left(1, p, u^{B}\right)=p X_{2}-\bar{w} m I-e_{b}-T
$$

Zero profit for good 2 in $B$ dictates:

$$
p X_{2}=\bar{w} L+w^{s B} \bar{S}=\bar{w} m(\bar{L}+I)+w^{s B} \bar{S} \Rightarrow p X_{2}-\bar{w} m I=\bar{w} \bar{L} m+w^{s B} \bar{S}
$$


Substituting (2.26) in (2.25)

$$
E^{B}\left(1, p, u^{B}\right)=\bar{w} \bar{L} m+w^{s B} \bar{S}-e_{b}-T
$$

Differentiating (2.27) with respect to $T$ we get

$$
E_{u}^{B} \frac{d u^{B}}{d T}=-E_{2}^{B} \frac{d p}{d T}+\bar{w} \bar{L} \frac{d m}{d T}+\bar{S} \frac{d w^{s B}}{d T}-1
$$

The first term on the right-hand-side of (2.28) is the loss to consumers of $B$ when the price of good 2 rises due to the transfer. The second term is a gain/loss to unskilled natives of $B$ due to a rise/fall in the employment rate in $B$. The third term is the gain/loss to the skilled natives due to a rise/fall in the skilled wage. The last term is the direct loss to $B$ due to the transfer. Because of constant returns to scale, we can write the zero profit condition in good 2 in nation $B$ as:

$$
C\left(\bar{w}, w^{s B}\right)=p
$$

where $C($.$) is the unit-cost function for good-2 in B$. Differentiating (2.29a) and using

Sheppard's lemma:

$$
\frac{d w^{s B}}{d p}=\frac{X_{2}}{\bar{S}}
$$

Substituting (2.29b) in (2.28), and using (2.21b) and (2.24), we can rewrite (2.28) as:

$$
E_{u}^{B} \frac{d u^{B}}{d T}=\left[\operatorname{Exp}_{2}^{B}+\bar{w} \bar{L} m^{\prime}(p)\right] p_{T}-1
$$

where $\operatorname{Exp}_{2}^{B}=X_{2}-E_{2}^{B}>0$, is the export of good 2 by nation $B$. Eq. (2.30) is analogous to Eq.

(2.17) above, and suggest that in an unemployment economy a positive terms of trade effect of a transfer will be reflected in terms of the standard effect (i.e., $\operatorname{Exp}_{2}^{B} p_{T}$ ) and the employment augmenting effect for unskilled labor (i.e., $\bar{w} \bar{L} m^{\prime} p_{T}$ ). Nation $B$ 's welfare will rise because of the transfer if these effects are larger than direct income loss due to the transfer. 


\section{Empirical Model, Data, and Estimation}

\subsection{Model specification}

The theoretical model developed above predicts that foreign aid to Central and Latin American nations has countervailing effects on illegal immigration to the U.S. Consistent with the conventional beliefs of the profession, the model does hold that increased aid (all else equal) reduces illegal immigration by boosting the income and material wellbeing of those living in the recipient nations. However, the model also predicts that aid distorts a recipient nation's terms of trade, thereby harming that nation's export sector and catalyzing greater migration flows. To determine the net effect of foreign aid on illegal immigration to the U.S. in practice, we empirically estimate the following system of equations (3.1):

$$
\begin{gathered}
\text { immigration }_{i t}=\beta_{1} \text { trade }_{i t-1}+\beta_{2} \text { tariff }_{i t}+\beta_{3} \text { tariff }_{i t}+\beta_{4} \text { unemployment }_{i t} \\
\beta_{5} \text { income }_{i t-1}+\beta_{5} \text { aid }_{i t-1}+\alpha_{i}+\eta_{t}+\varepsilon_{i t} . \\
\text { trade }_{i t}=\gamma_{1} \text { aid }_{i t-1}+a_{i}+\delta_{t}+u_{i t} .
\end{gathered}
$$

Starting with the first equation above (3.1a) immigration $_{i t}$ is the natural log of illegal immigrants from nation $i$ apprehended by U.S. authorities in year $t$. The first explanatory variable is trade $_{i t-1}$, which measures the natural log of the terms of trade from the prior period. The U.S. tariff applied to foreign imports is measured by tariff $1_{i t}$, while tariff $2_{i t}$ captures the average foreign tariff levied on U.S. exports. Foreign labor market conditions are measured by the corresponding unemployment rate ( unemployment $_{i t}$ ), and living standards are in-turn reflected by the natural $\log$ of real per capita income in the prior period. The parameters $\alpha_{i}$ and $\eta_{t}$ capture nation and period fixed effects respectively, while $\varepsilon_{i t}$ is an independently and identically distributed mean-zero shock. Turning to the second equation (3.1b), the definitions of trade and 
aid are identical to those given in first equation, while the parameters $a_{i}$ and $\delta_{t}$ are the respective nation and period fixed effects, and $u_{i t}$ is a mean zero shock.

While equation (3.1a) is a straightforward extension of Hanson and Spilimbergo (1999), equation (3.1b) warrants further discussion. ${ }^{12}$ We assume that aid is an exogenous variable, determined by U.S. geopolitical considerations, and independent of any other factors that influence the terms of trade. This assumption is advantageous as it implies that aid is uncorrelated with any omitted explanatory variables, thus allowing for the unbiased estimation of $\gamma_{1}$ in equation $(3.1 \mathrm{~b})$.

\subsection{Data}

A major empirical challenge is that the number of people attempting to enter the U.S. illegally is not directly observable. Following Hanson and Spilimbergo (1999), we instead use data on apprehensions from the Department of Homeland Security as our measure of illegal immigration. However, to make the migration flows comparable across nations, we normalize by the populations of the sending nations, and multiply by one million (thus expressing illegal immigration per one million home residents). The data include both apprehensions by U.S. Border Patrol agents of individuals attempting to cross U.S. borders illegally and apprehensions of individuals residing within the U.S. who either entered the U.S. illegally or entered legally but subsequently lost their legal status. ${ }^{13}$ Foreign aid is measured by net Official Development Assistance (ODA) normalized by each nation's total exports plus income transfers, and

\footnotetext{
${ }^{12}$ Hanson and Spilimbergo (1999) consider the effects of Mexican and U.S. wages and enforcement on illegal immigration (measured using apprehensions). We expand their analysis to consider a broader panel of countries, we add foreign aid to the analysis, and we endogenize the terms of trade. We use unemployment rates as a proxy for foreign labor market conditions (as we do not have reliable wage data), and fixed nation effects capture invariant idiosyncratic determinants of migration flows. Finally, our inclusion of time period effects captures changes in U.S. enforcement policy over the sample period.

${ }^{13}$ Over $90 \%$ of all apprehensions occur at U.S. borders.
} 
expressed on a 100-point scale. The ODA data are from the OECD-DAC database, while the export and income values are from the World Bank's World Development Indicators (WDI) database. We measure the price of exports of good 1 using the export unit value of a major nonoil product exported to the U.S. by each sending country. The price of imports of good 2 is measured by the import unit value of metal working machinery (SITC 737 rev.2). ${ }^{14}$ Terms of trade equal the ratio of export unit values to import unit values. Unit values are calculated using data from COMTRADE. Income per capita is expressed in PPP adjusted (constant 2000) dollars, and is from the World Bank's World Development Indicators (WDI) database. Data on unemployment rates were obtained from World Economic Outlook (WEO), and tariff data are from the TRAINS database. Our sample consists of 162 observations, covering 18 countries (see Table 1), with annual observations over the period 1996 to 2004. Variable definitions and summary statistics of the data are provided in Table 2 .

\subsection{Estimation}

Although one of the key implications of the theoretical model is that the receipt of foreign aid affects the recipient nation's terms of trade with the U.S., and that this eventually stimulates the flow of illegal immigration, we assume that this process operates with a lag - i.e. time must elapse between the receipt of the aid and the eventual migration of displaced workers. This is important because it implies that contemporaneous shocks to a nation's terms of trade are uncorrelated with contemporaneous shocks to immigration, or more precisely $\operatorname{cov}\left(\varepsilon_{i t}, u_{i t}\right)=0$. As such, separate equation-by-equation estimation of (3.1a) and (3.1b) is both unbiased and efficient.

\footnotetext{
${ }^{14}$ Like many other developing countries, the share of capital goods imports (such as metal working machinery) in total imports is very high. Imports of metal working machinery are therefore important for analyzing terms of trade.
} 
Estimation results for equation (3.1a) are provided in Table 3. To ensure the robustness of the results, several alternative specifications are also reported, whereby various explanatory variables are removed. Consistent with our theoretical model, the estimated trade coefficient is universally negative and statistically significant, averaging -0.378 in value. This implies that a ten percent increase in the prior-period terms of trade leads to a -3.78 percent decline in the rate of illegal immigration or alternatively a 10 percent decline in the prior-period terms of trade leads to a 3.78 percent increase in illegal immigration. Turning to U.S. tariff rates, the estimated coefficients are both negative and statistically significant in all but one specification, which is consistent with the hypothesis that tariffs affect illegal immigration through their effect on domestic prices. The average coefficient value on U.S. tariffs is -0.0075 , implying that a ten percentage-point increase in the applied tariff rate leads to a $-7.5 \%$ reduction in illegal immigration. By contrast, the applied foreign tariff rates on U.S. exports are statistically insignificant in every model specification. Not surprisingly, the estimated coefficient on the unemployment rate is positive and statistically significant in each specification of equation 3.1a. Specifically, the coefficient on unemployment averages 0.061 , implying that a 1 percentagepoint increase in a nation's current unemployment rate leads to a $6.1 \%$ increase in illegal immigration. Clearly, illegal immigration flows are extremely sensitive to foreign labor market conditions. Also consistent with our a priori expectations, the coefficient on the lag of log per capita income is negative and statistically significant. The average coefficient value is -2.529 , meaning that a one percent increase in the level of income in Central and Latin American nations leads to just over a $2.5 \%$ decline in illegal immigration. This result clearly comports well with the prior findings of Faini and Venturini (1993) and Todaro and Maruszko (1987). Finally, turning to the log of lagged aid, the point estimates are all negative and remarkably similar in 
magnitude across all five specifications. The aid coefficient is statistically significant in three of the five regressions, just failing to achieve the $10 \%$ significance threshold in the other two regressions [i.e. a p-value of $10.8 \%$ in specification (1), and a p-value of $13.6 \%$ in specification (4)]. The average coefficient value among the statistically significant aid coefficients is -0.135 , meaning that a ten percent increase in a nation's aid to export ratio will reduce illegal immigration by $1.35 \%$ in the following period. This captures the well documented income effect from the migration literature, whereby foreign aid reduces migration by raising living standards in recipient nations.

To ascertain the extent to which aid indirectly affects immigration by way of distorting the terms of trade, we examine estimates of equation (3.1b). Specification (1) in Table 4 assumes both fixed country and period effects, and the resulting coefficient on lagged aid equals -0.155 , with a corresponding $\mathrm{p}$-value of $3.6 \%$. Specification (2) includes country fixed effects, but no period effects. The coefficient on aid in this alternative model equals -0.098 , with a corresponding p-value of $2 \%$. The average coefficient value across these two specifications is 0.126, implying that a ten percent increase in aid (expressed as a fraction of a nation's export sector) reduces the recipient nation's terms of trade by $1.26 \%$. From the estimates of equation (3.1a), we have established that a reduction in a nation's terms of trade results in an increase in illegal immigration activity. Combining these two findings, the magnitude of the indirect effect of aid on immigration vis-à-vis trade equals 0.017 :

$$
\frac{\text { zimmigration }_{i t}}{\text { aaid }_{i t-2}}=\frac{\text { trade }_{i t-1}}{\partial \text { aid }_{i t-2}} \times \frac{\text { immigration }_{i t}}{\partial \text { trade }_{i t-1}}=\gamma_{1} \times \beta_{5} .
$$


In words, a ten percent increase in aid leads to a $0.17 \%$ indirect increase in illegal immigration two periods in the future. Clearly, the direct income effect of aid on immigration dominates the indirect effect of aid-induced changes in the terms of trade on immigration. The policy implications are quite clear: aid reduces illegal immigration, but there are unintended consequences which blunt the effectiveness of such a strategy. To date, we are unaware of any other empirical study which estimates the relative magnitude of this neglected aid-immigration channel.

\section{Conclusion}

This paper analyzes the effect of foreign aid on terms of trade within the context of a general equilibrium immigration model. Along the lines of the well-known transfer problem in the presence of distortionary trade taxes, we show that foreign aid may improve the donor's terms of trade and partially (or fully) offset the donor's loss from granting the aid. In addition, we consider the effect of such terms of trade changes on the wages of the donor and the recipient nations. If the wage difference between the nations is magnified by the change in the terms of trade, illegal immigration increases. We consider the welfare implication of such factor flows, taking into account their effect on factor prices.

Our empirical analysis of the effect of foreign aid on illegal immigration supports the predictions of the theoretical model. We find that the terms of trade effect of foreign aid significantly increases illegal immigration to the U.S. However, the direct income effect of aid on immigration dominates the indirect effect of aid-induced changes in the terms of trade on immigration. Overall, aid reduces illegal immigration, but there are unintended consequences which attenuate the effectiveness of such a strategy. 


\section{References}

Bandyopadhyay, S. (2006) "Illegal Immigration and Second Best Import Tariffs" Review of International Economics 14, 93-103.

Bond, E.W., and Chen, T.J. (1987) "The Welfare Effects of Illegal Immigration" Journal of International Economics 23, 315-328.

Brecher, R., and Bhagwati, J. (1982) "Immizerising Transfers from Abroad" Journal of International Economics 13, 353-364.

Camarota, S. (2007) "Immigrants in the United States, 2007: A Profile of America's ForeignBorn Population" Center for Immigration Studies, Washington, D.C.

Djajic, S. (2007) "Foreign Aid, International Migration and Welfare" in Sajal Lahiri (ed): Theory and Practice of Foreign Aid, Vol. 1, Elsevier.

Dixit, A., and Norman, V. (1980) Theory of International Trade. Cambridge University Press.

Ethier, W. (1986) "Illegal Immigration: The Host Country Problem" American Economic Review 76, 56-71.

Faini, R., and Venturini, A. (1993) "Trade, Aid, and Migrations: Some Basic Policy Issues" European Economic Review 37, 435-442.

Gaytan-Fregoso, H., and Lahiri, S. (2000) "Foreign Aid and Illegal Immigration" Journal of Development Economics 63, 515-527.

Hanson, G., and Spilimbergo, A. (1999) "Illegal Immigration, Border Enforcement, and Relative Wages: Evidence from Apprehensions at the U.S.-Mexico Border" American Economic Review 89, 1337-1357.

Myers, G., and Papageorgiou Y. (2000) "Immigration Control and the Welfare State" Journal of Public Economics 75, 183-207.

Ohyama, M. (1974) “Tariffs and the Transfer Problem” KEIO Economic Studies 11, 29-45.

“The Kamikazes of Poverty" The Economist, 2004, vol. 370, issue 8360, pp. 33-34.

Palivos, T. (2009) "Welfare Effects of Illegal Immigration", Journal of Population Economics, $22,131-44$.

Todaro, P., and Maruszko, L. (1987) "Illegal Migration and U.S. Immigration Reform: A Conceptual Framework" Population and Development Review 13, 101-114. 


\section{Table 1: Sample of Countries used in the Estimation}

\section{Region/Country}

\section{North America}

Mexico*

\section{Central America}

Belize

Costa Rica

El Salvador*

Guatemala*

Honduras*

Nicaragua*

Panama

\section{South America}

Argentina

Bolivia

Brazil

Chile

Colombia*

Ecuador*

Paraguay

Peru*

Uruguay

Venezuela

* Country is among the top 20 countries with the highest illegal immigrant population in the U.S. (Source: 1997 Yearbook) 


\section{Table 2: Variable Definitions and Summary Statistics}

\begin{tabular}{|c|c|c|}
\hline Variable & Definition & $\begin{array}{l}\text { Mean } \\
\text { (Standard } \\
\text { Deviation) } \\
\end{array}$ \\
\hline Apprehensions & $\begin{array}{l}\text { Apprehensions by the U.S. Border Patrol agents of individuals } \\
\text { attempting to cross the U.S. borders illegally, and } \\
\text { apprehensions by investigations agents of individuals who } \\
\text { entered the U.S. illegally and those who entered legally but } \\
\text { subsequently lost legal status, divided by home population and } \\
\text { multiplied by one million. }\end{array}$ & $\begin{array}{c}1,122.82 \\
(3,281.11)\end{array}$ \\
\hline Foreign aid & $\begin{array}{l}\text { Net Official Development Assistance normalized by total } \\
\text { exports plus income transfers, and expressed as a percentage } \\
(\%) \text {. }\end{array}$ & $\begin{array}{c}9.96 \\
(21.05)\end{array}$ \\
\hline Per-capita income & GDP per capita (PPP based, constant 2000 dollars) & $\begin{array}{c}5,885.07 \\
(2,528.85)\end{array}$ \\
\hline Terms of trade & Export unit value /import unit value & $\begin{array}{c}0.05 \\
(0.29)\end{array}$ \\
\hline Unemployment & $\begin{array}{l}\text { Unemployment rate of country } i \text {, expressed as a percentage } \\
(\%)\end{array}$ & $\begin{array}{l}9.66 \\
(4.25)\end{array}$ \\
\hline Tariff 1 & U.S. average applied tariff on imports good 1 (trade weighted) & $\begin{array}{c}4.46 \\
(20.48)\end{array}$ \\
\hline Tariff 2 & Average applied tariff on good 2 by country i (trade weighted) & $\begin{array}{c}7.70 \\
(3.97)\end{array}$ \\
\hline
\end{tabular}

Note: illegal immigrants' countries of origin are indexed by i. 
Table 3 - Estimates of Equation 3.1a

\section{Fixed Effect Panel Regressions: Various Model Specifications (dependent variable: immigration)}

\begin{tabular}{|c|c|c|c|c|c|c|}
\hline \multirow[b]{2}{*}{ Variable } & \multicolumn{6}{|c|}{ Alternative Specifications } \\
\hline & $(1)$ & $(2)$ & (3) & $(4)$ & $(5)$ & (6) \\
\hline \multirow[t]{2}{*}{ terms of trade } & -0.0380 & -0.0420 & --- & -0.0300 & -0.0400 & -0.0390 \\
\hline & $(0.017)^{* *}$ & $(0.021)^{*}$ & & $(0.017)^{*}$ & $(0.018)^{* *}$ & $(0.018)^{* *}$ \\
\hline \multirow[t]{2}{*}{ tariff on good 1} & -0.0060 & -0.0070 & -0.0060 & -0.0110 & --- & -0.0020 \\
\hline & $(0.003)^{* *}$ & $(0.003)^{* *}$ & $(0.003)^{* *}$ & $(0.004)^{* * *}$ & & $(0.002)$ \\
\hline \multirow[t]{2}{*}{ tariff on good 2} & -0.0110 & -0.0110 & -0.0110 & 0.0090 & --- & -0.0150 \\
\hline & $(0.022)$ & $(0.019)$ & $(0.024)$ & $(0.022)$ & & $(0.021)$ \\
\hline \multirow[t]{2}{*}{ unemployment rate } & 0.0570 & 0.0610 & 0.0580 & 0.0860 & 0.0410 & --- \\
\hline & $(0.022) * * *$ & $(0.018)^{* * *}$ & $(0.021)^{* * *}$ & $(0.018)^{* * *}$ & $(0.014)^{* * *}$ & \\
\hline \multirow[t]{2}{*}{ income } & -2.4020 & -1.8460 & -2.3250 & --- & -2.8050 & -3.2660 \\
\hline & $(0.368)^{* * *}$ & $(0.333)^{* * *}$ & $(0.431)^{* * *}$ & & $(0.278)^{* * *}$ & $(0.397)^{* * *}$ \\
\hline \multirow[t]{2}{*}{ aid } & -0.132 & --- & -0.135 & -0.1000 & -0.1380 & -0.1330 \\
\hline & (0.081) & & $(0.08)^{*}$ & $(0.067)$ & $(0.077)^{*}$ & $(0.08)^{*}$ \\
\hline Goodness of fit $\left(R^{2}\right)$ & 0.98 & 0.98 & 0.98 & 0.98 & 0.98 & 0.98 \\
\hline Observations & 140 & 144 & 140 & 140 & 140 & 140 \\
\hline \multicolumn{7}{|c|}{ White robust standard errors in parenthesis } \\
\hline \multicolumn{7}{|c|}{$* * *, * *, * *$ - statistically significant at the one, five, and ten percent levels respectively } \\
\hline \multicolumn{7}{|c|}{ Specifications ( 1 ) to (6) contain both fixed nation and period effects } \\
\hline
\end{tabular}




\section{Table 4 - Estimates of Equation 3.1b}

Fixed Effect Panel Regressions: Various Model Specifications (dependent variable: trade)

\begin{tabular}{lcc} 
& \multicolumn{2}{c}{ Alternative Specifications } \\
\cline { 2 - 3 } Variable & $(1)$ & $(2)$ \\
\hline aid & -0.155 & -0.098 \\
& $(0.071)^{* *}$ & $(0.041)^{* *}$ \\
\hline
\end{tabular}

Goodness of fit $\left(R^{2}\right)$

0.78

0.76

Observations 140 140

White robust standard errors in parenthesis

$* * *, * *, * *$ - statistically significant at the one, five, and ten percent levels respectively

Specification (1) contains both fixed period and nation effects Specification (2) contains just fixed nation effects 
Figure 1: Enforcement of U.S.-Mexico Border

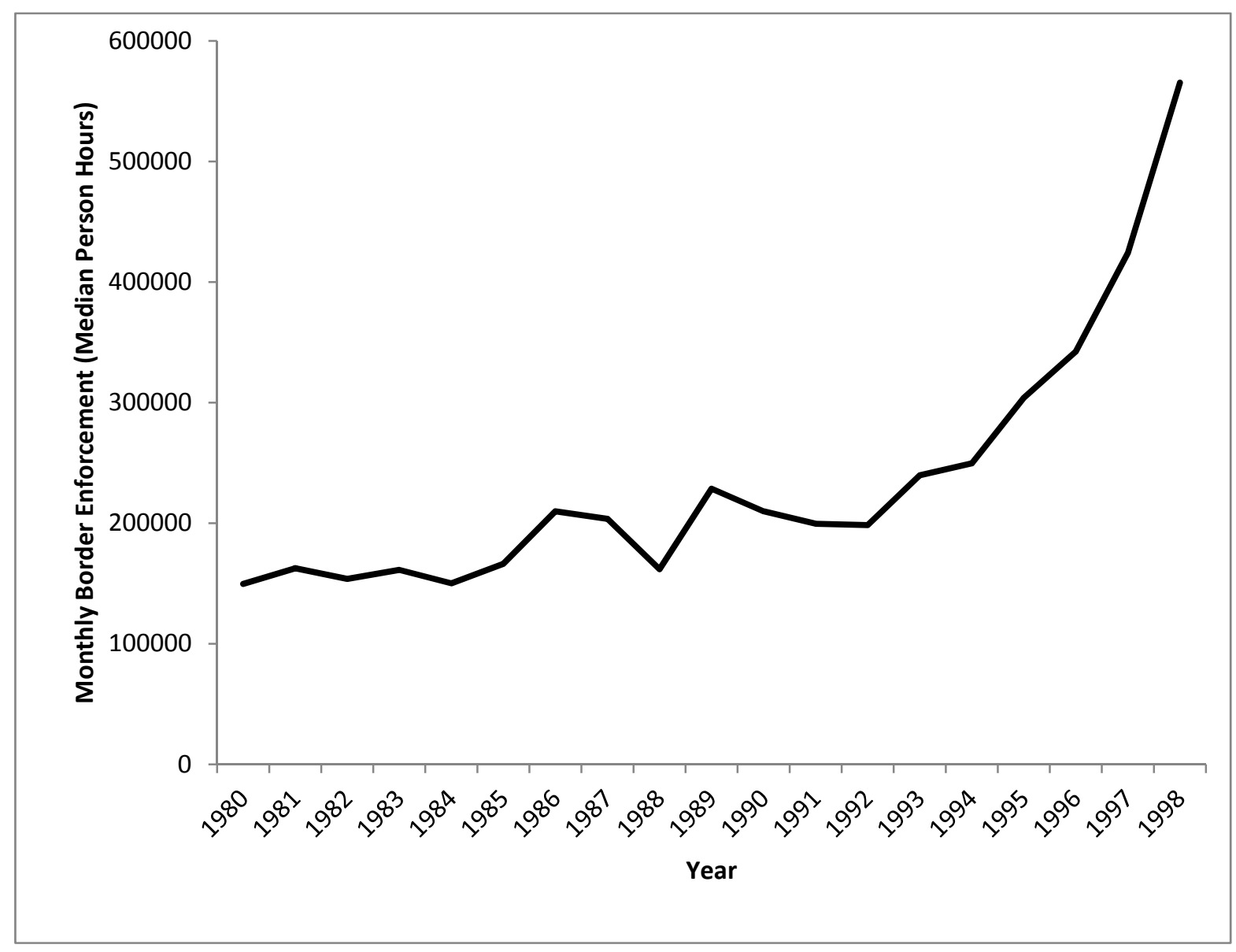

